\title{
Analisa Segmenting, Targetting, Positioning, dan SWOT Sebagai Strategi Pemasaran Kopi Karlos (Studi pada Produsen Kopi Karlos Desa Donowarih Kecamatan Karangploso Kabupaten Malang)
}

\author{
Segmenting, Targetting, Positioning, and SWOT Analysis As a Market Strategy \\ of Kopi Karlos (Study on Karlos Coffe Producers at Donowarih Village, \\ Karangploso District, Malang Regency)
}

\section{Maulidya Alfi A. Z., Vira Rizky Augusta, Annisa Nur Hidayah, Zehri Dwi Irwansyah, Septian Eka Prastiwi, Puguh Pedana Putra, Ventisiya Tri Arima, Han Arveian \\ Fakultas Ilmu Administrasi Universitas Brawijaya}

DOI:https://doi.org/10.32781/cakrawala.v12i1.264

\section{Received : 27 Januari 2018 \\ Accepted : 9 Mei 2018 \\ Published : 21 Mei 2018}

\begin{abstract}
Abstrak:
Kopi menjadi komoditas unggulan dalam sektor pertanian Indonesia. Salah satu daerah yang menjadi penghasil kopi terbesar adalah Malang, Jawa Timur. Kopi yang menjadi daya tarik dari kopi malang adalah Kopi Karlos. Kopi Karlos merupakan salah satu brand kopi kecamatanKarangploso, Malang dengan jenis kopi arabica. Namun, pemasaran biji kopi Karlos terbilang sempit, yaitu secara business-to-business. Padahal, tingkat konsumsi kopi nasional meningkat dengan Compound Annual Growth Rate (CAGR) 7,7\%. Penelitian ini mengambil judul Analisis Segmenting, Targetting, Positioning (STP) dan Strength, Weakness, Opportunity, dan Threat (SWOT) sebagai Strategi Pemasaran Kopi Karlos. Penelitian menggunakan teori Segmenting, Targetting, dan Positioning serta Strength, Weakness, Opportunity, dan Threat sebagai teori yang mewakili strategi pemasaran. Penelitian ini menggunakan jenis penelitian analisis deskriptif dengan pendekatan kualitatif. Sumber data penelitian ini dari hasil observasi, artikel, dan interview pemilik Cafe After Taste, Amstirdam Cafe \& Roastry, dan Konsumen Kopi Karlos. Metode Analisis penelitian ini menggunakan metode analisis Miles, Hubberman, dan Saldana (2014). Hasil penelitian menunjukkan bahwa segmenting dari Kopi Karlos memasarkan produknya di daerah pulau Jawa, dibedakan berdasarkan pengolahan dengan mengungulkan jenis Honey dengan rasa di akhir. Targetting Kopi Karlos yaitu konsumen dengan ekonomi menengah ke bawah, khususnya kalangan mahasiswa. Positioning Kopi Karlos yaitu produk kopi dengan cita rasa asam di akhir. Strength dari Kopi Karlos adalah tersedianya berbagai jenis kopi berdasarkan pengolahannya, salah satunya jenis Honey yang menjadi pembeda dari kopi lokal di dalam pasar kopi arabica.Weakness dari Kopi Karlos yaitu kurangnya konsistensi dalam pengolahan kopi pasca panen. Opportunity dari Kopi Karlos adalah meningkatnya penikmat kopi lokal, khususnya Kopi Karlos. Threat dari Kopi Karlos yaitu munculnya kompetitor dengan produk kopi lokal. Saran dari peneliti yaitu diperlukan adanya penelitian lebih lanjut mengenai strategi pemasaran kopi lokal dan perlunya penyediaan pelatihan mengenai pengolahan kopi pascapanen.
\end{abstract}

Kata kunci: Kopi Karlos, Segmenting, Targetting, Positioning, SWOT

\section{Abstract:}

Coffee becomes a pivotal commodity in the Indonesian agricultural sector. One of the biggest coffee producing regions is Malang, East Java with coffee commodities as the leading agricultural products. Coffee that is the main attraction of the poor coffee is Kopi Karlos. Kopi Karlos is one brand of coffee district Karangploso, Malang with the type of arabica coffee. However, marketing of coffee beans is fairly narrow, ie business-to-business. In fact, the national coffee consumption level increased with the Compound Annual Growth Rate (CAGR) of 7.7\%. This research takes the title of Segmenting Analysis, Targetting, Positioning (STP) and Strength, Weakness, Opportunity, and Threat (SWOT) as Karlos Coffee Marketing Strategy. The research used Segmenting, Targetting, and Positioning and Strength, Weakness, Opportunity, and Threat as theories that represent marketing strategy. This research uses descriptive analysis with qualitative approach. Sources of this research data from the results of observations, articles, and interviews of Cafe After Taste owners, Amstirdam Cafe \& Roastry, and Consumers Coffee Karlos. Methods Analysis of this study using methods of analysis Miles, Hubberman, and Saldana (2014). The results showed that the segmenting of Kopi Karlos marketed its products in the island of Java, distinguished by processing by raising the type of Honey with taste at the end. Targetting of Kopi Karlos is consumer with middle to lower economy, especially among students. Kopi Karlos Positioning is a coffee product with a sour taste at the end. Strength of Kopi Karlos is the availability of various types of coffee based on its processing, one of which is Honey which distinguishes the local coffee in arabica. Weakness from Kopi Karlos is a lack of consistency in post-harvest coffee processing. Opportunity of Kopi Karlos is the increase of local coffee lovers, especially Kopi Karlos. Threat of Kopi Karlos is the emergence of competitors with local coffee products. The researcher's suggestion is that there is a need for further research on local coffee marketing strategy and the need to provide training on post-harvest coffee processing.

Keywords: Kopi Karlos, Segmenting, Targetting, Positioning, SWOT

How to Cite:

Maulidya Alfi A. Z., Vira Rizky Augusta, Annisa Nur Hidayah, Zehri Dwi Irwansyah, Septian Eka Prastiwi, Puguh Pedana Putra, Ventisiya Tri Arima, Han Arveian (2018). Analisa Segmenting, Targetting, Positioning, dan SWOT Sebagai Strategi Pemasaran Kopi Karlos (Studi pada Produsen Kopi Karlos Desa Donowarih Kecamatan Karangploso Kabupaten Malang). Cakrawala, 12(1), 41-62.

\footnotetext{
* Corresponding Author:

Nama : Maulidya Alfi A. Z., Zehri Dwi Irwansyah

Email : alfimaulidya375@gmail.com, zehrirwansyah@gmail.com

Contact :
}

(C) 2018 Badan Penelitian dan Pengembangan Provinsi Jawa Timur 


\section{Pendahuluan}

Indonesia merupakan negara agraris di mana sebagian besar penduduknya hidup dari hasil bercocok tanam atau bertani, sehingga pertanian merupakan sektor yang memegang peranan penting dalam kesejahteraan kehidupan penduduk Indonesia. Hal tersebut juga didukung oleh iklim Indonesia yang tropis, membuat Indonesia mendapat sinar matahari sepanjang tahun, curah hujan yang tinggi membuat tanah Indonesia menjadi subur sehingga dapat mendorong masyarakat Indonesia untuk bertani atau bercocok tanam serta berkebun. Pada tahun 2017 pertanian Indonesia berada pada posisi 25 terbaik di dunia, peringkat itu diberikan oleh lembaga riset dan analisis ekonomi internasional yakni The Economicst Intelegent Unit (EIU) dan Barilla Center for Food and Nutrion (BCFN) Foundation (ekonomi.kompas.com). Berdasarkan data Badan Pusat Statistik (BPS) yang mengungkapkan bahwa sektor pertanian pada kuartal pertama 2017 tumbuh 15,59\% dibandingkan periode sama tahun sebelumnya. PDB sektor pertanian kuartal pertama 2017 juga meningkat $7,12 \%$ dibandingkan kuartal yang sama 2016, melebihi keniakan PDB industri pengolahan $4,21 \%$ maupun total Indonesia 5,01\% (ekonomi.kompas.com).

Pertanian adalah kegiatan manusia dalam membuka lahan dan menanaminya dengan berbagai jenis tanaman yang termasuk tanaman semusim maupun tanaman tahunan dan tanaman pangan maupun tanaman non-pangan serta digunakan untuk memelihara ternak maupun ikan. Berdasakan berbagai tujuan dan alasan lahan dibuka yang kemudian diusahakan oleh manusia. Pertanian dianggap sebagai sumber kehidupan lapangan kerja. Pertanian dapat mengandung dua arti yaitu (1) dalam arti sempit atau sehari-hari diartikan sebagai kegiatan cocok tanam dan (2) dalam arti luas diartikan sebagai kegiatan yang menyangkut proses produksi menghasilkan bahan-bahan kebutuhan manusia yang dapat berasal dari tumbuhan maupun hewan yang disertai dengan usaha untuk memperbaharui, memperbanyak (reproduksi) dan mempertimbangkan faktor ekonomis (Suratiyah,2006). Banyak hasil pertanian Indonesia yang berhasil menjadi primadona untuk di ekspor, banyak importer yang memesan hasil - hasil pertanian tersebut untuk memenuhi permintaaan yang tinggi di negaranya. Hasil pertanian Indonesia yang diakui kualitasnya oleh dunia: teh, kakao atau cokelat, kayu manis, buah manggis, kopi, buah jambu merah, dan sirsak (emporodigital.com).

Indonesia merupakan negara penghasil kopi dalam jumlah yang banyak, perkebunan kopi tersebar di seluruh wilayah Indonesia dengan khasnya masing-masing. Kopi dari Indonesia ini merupakan salah satu produk pertanian yang berkualitas di dunia. Salah satunya adalah kopi luwak. Kopi yang salah satu prosesnya melalui bantuan hewan luwak ini memanghanya berasal dari Indonesia sehingga banyak diburu baik oleh penikmat kopi dari Indonesia mupun yang berasal dari luar negeri. Selain itu, rasa kopi yang berasal dari Indonesia cukup unik dan berbeda. Rasanya lezat dan memiliki ciri khas rasa lain seperti kopi dengan aroma jeruk, yaitu kopi Bali dan kopi dengan aroma kacang-kacangan, yaitu kopi Papua (emporodigital.com).

Jawa timur menghasilkan kopi spesialti dunia Arabika (High level kopi spesialti dunia) Java coffe 3000 - 5000 ton dan robutsa specialti (on progress/promotion) Java robusta WIB 10.000 15000 ton. Daerah penghasil kopi Jatim yaitu Kabupaten Jember, Banyuwangi, Situbondo, Bondowoso, Malang dan Jombang sudah dikenal di luar negeri. Kopi yang dihasilkan di Jatim sudah dikenal di luar negeri karena mempunyai karakteristik dan citarasa yang khas (spesialti) (gaeki.or.id/areal-dan-produksi/). Malang memiliki potensi dalam sektor pertanian maupun perkebunan, hasil perkebunan yang menjadi komiditi perkebunan Malang yang menjadi keunggulan Indonesia adalah kopi. Perkebunan kopi banyak tersebar di daerah Malang, salah satu daerah yang memiliki potensi daerah yang besar adalah Kecamatan Karangploso. Kecamatan Karangploso terletak sebelah selatan kaki Gunung Arjuna bahkan sebagian dusunnya berada di lereng gunung, topografi berupa dataran dan perbukitan serta berada pada ketinggian 600 sampai dengan $850 \mathrm{~m}$ dari permukaan air laut sehingga mengakibatkan desa ini berhawa sejuk dan dingin. Kecamatan Karangploso memiliki potensi daerah yang melimpah diantaranya adalah pada sektor kehutanan, kerajinan, perkebunan, pertambangan, pertanian, peternakan (situs pemerintah Kabupaten Malang,2014) 
Sektor Pertanian pada Kecamatan Karangploso menghasilkan tanaman pangan yaitu : padi, jagung manis, pertanian hortikultura, sayur-mayur, buah dan kopi yang di imbangi dengan sentra pasar sayur mayur yang terus berkembang. Desa yang mendukung potensi pertanian Kecamatan Karangploso adalah Desa Donowarih. Desa Donowarih merupakan salah satu potensi daerah Kabupaten Malang yang dapat dikembangkan karena mempunyai tanah yang subur untuk usaha pertanian sehingga masyarakat sebagian besar mempunyai usaha pertanian sayur-mayur, padi, buah dan jagung, dalam bidang peternakan Desa Donowarih mampu menghasilkan susu, sedangkan dalam bidang perkebunan mampu menghasilkan kopi, kopi yang dihasilkan petani Desa Donorawih berbeda dengan kopi daerah lainya, kopi ini memiliki tingkat keasaman yang mendekati jeruk nipis dengan akhir rasa coklat yang tertinggal cukup lama (kopiluwakamstirdam.com). Kopi ini dinamai kopi Karlos, sebagai brand yang dihasilkan Kecamatan Karangploso.

Keadaan topografi Desa Donowarih memiliki ketinggian 1100 -1200 dpl serta suhu $16^{\circ} \mathrm{C}-20^{\circ} \mathrm{C}$ cocok untuk digunakan menanam kopi, jenis kopi yang ditanam di Desa Donowarih adalah kopi Arabica dengan varietas lini S dan cobra 790 (berdasarkan observasi peniliti). Dengan varietas yang unggul dan teknik pengolahan kopi yang benar menghasilkan kopi yang berbeda dengan kopi unggulan daerah lainnya. Jenis kopi yang dihasilkan di Kecamatan Karang Ploso : kopi natural, kopi full wash, kopi semi full wash, dan kopi honey, kopi tersebut berasal dari varietas yang sama aka tetapi memiliki cita rasa yang berbeda, hal yang membedakannya terletak pada proses pengolahan kopi (hasil dari observasi). Kopi Karlos sendiri banyak sekali peminatnya kebanyakan kedai kopi malang menggunakan kopi Karlos selain itu kopi Karlos juga di pasarkan ke kota lain seperti di Bandung, di Bandung sendiri terdapat lima kedai kopi yang menggunakan produk kopi Karlos (berdasarkan sumber hasil wawancara dengan Bapak Muji pengelola kopi Karlos ).

Pemasaran biji Kopi Karlos masih bisnis to bisnis (B2B ) sehinga yang membeli biji kopi Karlos kedai - kedai kopi atau café. Kotler \& Keller, 2016 menyatakan bahwa "The business market consists of all the organizations that acquire goods and services used in the production of other products or services that are sold, rented, or supplied to others". Bisnis Market terdiri dari semua organisasi yang memperoleh barang dan jasa yang digunakan untuk memproduksi produk atau jasa lain yang dijual, disewakan atau dipasok kepada orang lain, setiap perusahaan yang memasok komponen untuk produk dalam pasar bisnis to bisnis (B2B). Bentuk transaksi Bisnis to Bisnis yang nyata yaitu dimana produsen dan atau penyedia layanan menjual produk ke bisnis lain, akan tetapi ruang lingkup pasar bisnis tidak hanya melayani pasar bisnis akan tetapi melayani pelanggan Pemerintah, lembaga pendidikan, rumah sakit maupun reseller. Pemasaran biji kopi Karlos yang bisnis to bisnis membuat pasar biji kopi Karlos sempit, meskipun sempit karena hanya menjual biji kopi kepada kedai - kedai kopi dan café karena biji kopi yang jual masih butuh proses finishing yang membutuh peralatan untuk penyanggraihan kopi dan penghasulan kopi agar biji kopi bisa dinikmati oleh penikmat kopi. Meskipun sempit pemasarannya bukan berarti lebih mudah dalam pengelolaanya, karena dibutuhkan hubungan yang baik antara pemasok dan pelanggan bisnis sehingga tercipta keunggulan kompetitif yang berkesinambungan dalam rangka membangun dan menciptakan loyalitas pelanggan. Strategi pemasaran pada bisnis to bisnis, para bisnis tidak melakukan pembelian karena nilai emosional tetapi cenderung bersifat rasional. Pelanggan bisnis to bisnis lebih memperhatikan komponen harga dan kualitas serta fungsi yang ditawarkan oleh suatu produk, selain nilai fungsional.

Pada tahun 2012, sekitar 70\% dari total produksi tahunan biji kopi Indonesia diekspor, terutama kepada para pelanggan di Jepang, Afrika Selatan, Eropa Barat, dan Amerika Serikat. Konsumsi domestic kopi Indonesia telah tumbuh, akan tetapi jumlah ekspor telah menurun. Konsumsi kopi di Indonesia meningkat dengan compound annual growth rate (CAGR) $7,7 \%$ di tahun 2014. Oleh karena hal tersebut maka diperlukan strategi pemasaran yang tepat agar menjadikan biji kopi Karlos bertahan di pasaran. Pendekatan strategi pemasaran dengan menggunakan analisis Strenght, Targetting, Positioning (STP) dan metode analisis SWOT akan membantu dalam pemasaran biji Karlos, sehingga mampu meningkatkan kesejahteraan petani kopi Karlos di Desa Donowarih Kecamatan Karang Ploso karena dengan meningktanya 
permintaan kopi Karlos maka akan meningkatkan jumlah produksi kopi Karlos serta meningkatkan harga jual kopi Karlos. Berdasarkan paparan tersebut peneliti tertarik untuk melakukan pembahasan yang mendalam sehingga penelitian ini mengangkat judul Analisa Segmenting, Targetting, Positioning, dan SWOT sebagai Strategi Pemasaran Kopi Karlos (Studi pada Produsen Kopi Karlos Desa Donowarih Kecamatan Karangploso Kabupaten Malang).

\section{Tinjauan Pustaka}

\section{A. Pemasaran}

Pemasaran adalah suatu fungsi organisasi dan serangkaian proses untuk menciptakan, mengkomunikasikan, dan memberikan nilai kepada pelanggan dan untuk mengelola hubungan pelanggan dengan cara menguntungkan organisasi dan pemangku kepentingannya (Kotler dan Keller ,2008). Pemasaran adalah sekelompok aktivitas yang saling berkaitan yang dirancang untuk mengidentifikasi kebutuhan konsumen dan mengembangkan distribusi, promosi, dan penetapan harga serta pelayanan untuk memuaskan kebutuhan konsumen pada tingkat keuntungan tertentu (Kismono, 2011)

Berdasarkan definisi pemasaran yang dikemukakan oleh ahli tersebut dapat disimpulkan bahwa pemasaran merupakan suatu sistem dari kegiatan bisnis yang saling berhubungan dan ditujukan untuk merencanakan, mendistribusikan dan mempromosikan barang dan jasa yang dilakukan oleh perusahaan untuk memenuhi keinginan dan kebutuhan konsumen sekaligus untuk mencari keuntungan, sekaligus dengan mengoordinasikan dan mengelola atau memanajemennya dengan baik. Terdapat beberapa konsep penting yaitu kebutuhan, keinginan, dan permintaan produk (barang, jasa, dan ide), nilai, biaya, dan kepuasan, pertukaran dan transaksi, hubungan relasi dan jaringan kerja, serta pemasar dan prospek. Tanpa adanya kegiatan pemasaran, konsumen akan tetap berada dalam kondisi subsistem, yaitu suatu kondisi dimana segala kebutuhannya dicukupi sendiri.

Terdapat paradigma dalam pemasaran yang juga berpengaruh terhadap pemasaran produk. Paradigma adalah bagaimana memandang dunia, paradigma menjelaskan kepada kita tentang dunia dan dapat membantu untuk memprediksikan perilakunya. Pergeseran paradigma dalam pemasaran tidak selalu menimbulkan perubahan pada definisi pemasaran yang ada sekarang. Ditinjau dari aspek manajerial dalam pergeseran paradigma pemasaran menunjukkan suatu proses atau sebagai proses pengambilan keputusan manajemen yang mencakup analisis, perencanaan, implementasi dan pengendalian dibidang pemasaran. Pengambilan keputusan manajemen lebih memfokuskan kepada empat aspek tersebut. Sedangkan tinjauan dari aspek perilaku konsumen dalam pergeseran paradigma pemasaran menunjukan bahwa semua keputusan konsumen atau pelanggan dijadikan dasar untuk pengambilan keputusan (Basu, 2004).

\section{B. Strategi Pemasaran}

Menurut Chandra (dalam Dimas, dkk 2015), strategi pemasaran merupakan rencana yang menjabarkan ekspektasi perusahaan akan dampak dari berbagai aktivitas atau program pemasaran terhadap permintaan produk atau lini produknya di pasar sasaran tertentu. Program pemasaran meliputi tindakan-tindakan pemasaran yang dapat mempengaruhi permintaan terhadap produk, diantaranya dalam hal mengubah harga, memodifikasi kampanye iklan, merancang promosi khusus, menentukan pilihan saluran distribusi, dan sebagainya. Strategi pemasaran adalah sebagai suatu tindakan penyesuaian untuk mengadakan reaksi terhadap situasi lingkungan tertentu (baru dan khas) yang dapat dianggap penting, karena tindakan penyesuaian tersebut dilakukan secara sadar berdasarkan pertimbangan yang wajar. Strategi pemasaran adalah logika pemasaran dan berdasarkan itu, unit bisnis diharapkan untuk mencapai sasaran-sasaran pemasarannya. Strategi pemasaran terdiri dari pengambilan keputusan tentang biaya pemasaran dari perusahaan, bauran pemasaran dan alokasi pemasaran dalam hubungannya dengan keadaan lingkungan yang diharapkan dan alokasi pemasaran (Afianda, 2015). 
Strategi pemasaran adalah usaha yang dilakukan untuk mendapatkan keuntungan. Upaya ini hanya dapat dilakukan jika perusahaan dapat mempertahankan dan meningkatkan penjualannya melalui usaha mencari pelanggan dan meyakinkan agar dapat mencapai pangsa pasar yang luas. Strategi Pemasaran merupakan rencana yang menyeluruh dan terpadu dibidang pemasaran sehingga kegiatan perusahaan dapat bertahan serta kontinyu. Sehingga dalam penentuan strategi pemasaran harus didasarkan atas analisis lingkungan internal dan eksternal melalui analisis keunggulan dan kelemahan serta peluang dan ancaman yang dihadapi perusahaan yang disiapkan oleh sebuah organisasi untuk mencapai sasaran-sasarannya (Kotler dalam Istiatin dan Sudarwati, 2015). Berdasarkan pendapat beberapa ahli dapat disimpulkan bahwa strategi pemasaran merupakan suatu kegiatan yang dirancang seseorang maupun tim dalam menjalankan sebuah usaha atau bisnis yang berkaitan dengan cara menarik konsumen, mempublikasikan produknya, hingga pengambilan keputusan mengenai biaya pemasaran. Strategi pemasaran dibuat dengan tujuan menghidupkan dan mengantisipasi adanya hambatan sebuah produk agar mampu bersaing dengan para kompetitor di pasar.

Strategi pemasaran berkaitan dengan sasaran-sasaran dan hasil yang dicapai dalam kegiatan pemasaran. Strategi Pemasaran banyak digunakan oleh orangorang yang bergerak dibidang bisnis, yang bertujuan supaya terjadi pertukaran, sehingga produk memiliki nilai lebih tinggi. Strategi pemasaran adalah keseluruhan tindakan-tindakan, agar kelangsungan hidup perusahaan terjaga serta kemajuan dan keunggulan dalam bisnis, maka pebisnis berupaya menerapkan strategi berupa bauran pemasaran dengan harapan untuk menciptakan minat pelanggan (Kotler dalam Istiatin, dan Sudarwati, 2015). Mendesain suatu strategi pemasaran, hal terpenting yang perlu dilakukan oleh manajemen pemasaran adalah penerapan konsep STP (segmentation, Targetting, positioning).

\section{Segmenting}

Segmentasi pasar adalah suatu proses untuk membagi-bagi atau mengelompokkelompokkan konsumen ke dalam kotak-kotak yang lebih homogen (Kasali, 2001). Segmentasi pasar juga dapat diartikan sebagai usaha untuk membagi pasar ke dalam kelompok-kelompok yang dapat dibedakan satu sama lain dalam hal kebutuhan, karakteristik, atau perilaku yang mungkin akan memerlukan produk-produk dan strategi pemasaran tertentu untuk menjangkaunya (Kotler dan Amstrong, 2003).

Menurut Tjipjono (2001) segmentasi pasar adalah proses membagi pasar keseluruhan suatu produk atau jasa yang bersifat heterogen ke dalam beberapa segmen, yang masing-masing segmennya cenderung bersifat homogen dalam segala aspek. Weinstein, Malcom \& Ian Dunbar, Rao \& Steckel dan Stanton, Etzel dan Walker mendefiniskansegmentasi adalah proses pembagian pasar ke dalam kelompok kelompok berdasarkan kesamaan kebutuhan atau karakteristik yang serupa dalam perilaku pembelian konsumen. Sebab-sebab segmentasi pasar:

a. Kebutuhan yang berbeda

b. Pola pembelian yang berbeda

c. Tanggapan yang berbeda terhadap penawaran

Dasarnya segmentasi pasar merupakan suatu strategi yang didasarkan pada falsafah manajemen pemasaran yang berorientasi pada konsumen. Penerapan dengan melaksanakan segmentasi pasar, kegiatan pemasaran dapat dilakukan lebih terarah, dan sumber daya perusahaan dibidang pemasaran dapat digunakan secara lebih efektif dan efisien (Rismiati dan Suratno, 2001). Tujuan dari segmentasi pasar adalah untukmenghemat usaha-usaha pemasaran dengan menitik beratkan kepada pembeli yang berminat tinggi untuk membeli. Selain itu segmentasi dilakukan untuk menghubungkan antara kebutuhan dengan tindakan. Menurut Kasali (2003), sedikitnya ada 5 manfaat yang diperoleh dengan melakukan segmentasi pasar, yaitu: 
1) Memodifikasi produk-produk yang lebih responsif terhadap kebutuhan pasar

Memperbarui ulang produk dengan memahami segmen-segmen yang responsif terhadap suatu stimuli, maka perusahaan dapat mendisain produk sesuai dengan kebutuhan atau keinginan segmen tersebut. Jadi perusahaan menempatkan konsumen di tempat utama dalam mendisain produk, dan menyesuaikan produknya untuk memuaskan konsumen (customersatisfactionataprofit).

2) Menganalisis pasar Mempelajari segmentasi pasar untuk membantu eksekutif mendeteksi siapa saja yang akan menjadi pesaing pasar produknya. Tidak semua pesaing perusahaan memproduksi produk yang sama dengan yang kita pasarkan Pesaing perusahaan adalah mereka yang mampu menjadi alternatif bagi kebutuhan konsumen.

3) Menemukan peluang (niche)

Setelah menganalisis pasar, perusahaan yang menguasai konsep segmentasi yang baik akan sampai pada ide menemukan peluang. Peluang ini tidak selalu sesuatu yang besar, tapi pada masanya peluangakan menjadi besar. Perlu diingat konsumen akan selalu belajar mengenali sesuatu atau mengikuti orang lain, atau merasa butuh terhadap suatu produk.

4) Menguasai posisi yang superior dan kompetitif

Perusahaan yang menguasai segmen dengan baik umumnya adalah mereka yang paham betul konsumennya dan telah mempelajari pergeseranpergeseran yang terjadi dalam segmennya.

5) Menentukan strategi komunikasi yang efektif dan efisien

Perusahaan mengetahui secara tepat siapa segmen pasar, maka perusahaan akan mengetahui cara berkomunikasi yang baik dengan para pelanggannya. Tidak ada cara tunggal untuk membuat segmen pasar. Seorang pemasar harus mencoba variabel segmentasi yang berbeda, sendiri atau dalam kombinasi, mencari cara terbaik untuk memandang struktur pasar.

Menurut Kotler dan Amstrong (2001), terdapat empat variabel utama yang mungkin dipergunakan dalam mensegmentasi pasar konsumen yaitu:

1) Segmentasi geografik

Segmentasi geografik membagi pasar menjadi beberapa unit secara geografik seperti negara, regional, negara bagian, kota atau kompleks perumahan. Sebuah perusahaan mungkin memutuskan untuk beroperasi dalam satu atau beberapa wilayah geografik ini, atau beroperasi di semua wilayah, tetapi lebih memperhatikan perbedaan kebutuhan dan keinginan yang dijumpai.

2) Segmentasi demografik

Segmentasi demografik membagi pasar menjadi kelompok berdasarkan pada variabel seperti umur, jenis kelamin, besar keluarga, siklus kehidupan keluarga, pendapatan, pekerjaan, pendidikan, agama, ras, dan kebangsaan. Faktor-faktor demografik merupakan dasar paling populer untuk membuat segmentasi kelompok pelanggan. Salah satu alasan adalah kebutuhan konsumen, keinginan dan tingkat penggunaan seringkali amat dekat dengan variabel demografik. Alasan lain adalah variabel demografik lebih mudah diukur ketimbang tipe variabel yang lain.

3) Segmentasi psikografik

Segmentasi psikografik membagi pembeli menjadi kelompok berbeda berdasarkan pada karakteristik sosial, gaya hidup atau kepribadian. Orang yang berada dalam kelompok demografik yang sama dapat saja mempunyai ciri psikografik berbeda.

4) Segmentasi tingkah laku

Segmentasi tingkah laku mengelompokkan pembeli berdasarkan pada pengetahuan, sikap, penggunaan atau reaksi mereka 
terhadap suatu produk. Banyak pemasar yakin bahwa variabel tingkah laku merupakan awal paling baik untuk membentuk segmen pasar.

\section{Targetting}

Definisi Targetting menurut Keegan \& Green (2008) adalah proses pengevaluasian segmentasi dan pemfokusan strategi pemasaran pada sebuah negara, propinsi, atau sekelompok orang yang memiliki potensi untuk memberikan respon. Target pasar dapat juga diartikan sebagai kegiatan yang berisi dan menilai serta memilih satu atau lebih segmen pasar yang akan dimasuki oleh suatu perusahaan. Targetting merupakan proses mengevaluasi dan memilih satu atau beberapa segmen pasar yang dinilai paling menarik untuk dilayani dengan program pemasaran spesifik perusahaan (Tjiptono, 2012). Pemilihan segmen pasar dengan adanya Targetting dapat memberikan kemudahan produsen dalam memasarkan sebuah produk.

Ada lima faktor yang perlu diperhatikan sebelum menetapkan target pasar yaitu (Rismiati dan Suratno, 2001):

a. Ukuran segmen

Perkiraan besarnya ukuran segmen yang akan ditinjau merupakan faktor penting untuk memutuskan apakah segmen pasar tersebut cukup berharga untuk ditindak lanjuti. Perusahaan yang besar akan memilih segmen dengan volume penjualan besar dan menghindari segmen kecil dan sebaliknya.

b. Pertumbuhan segmen

Meskipun ukuran segmen saat ini kecil bukan tidak mungkin akan berkembang atau diharapkan dapat berkembang untuk masa mendatang.

c. Biaya yang harus dikeluarkan untuk mencapai segmen tersebut.

Suatu segmen yang tidak cocok dengan kegiatan pemasaran perusahaan seharusnya tidak dikejar.

d. Kesesuaian dengan tujuan dan sumber-sumber/kemampuan perusahaan Target yang dituju haruslah sesuai dengan tujuan dan sumbersumber/kemampuan yang dimiliki perusahaan / posisi persaingan

Suatu segmen mungkin mempunyai ukuran dan pertumbuhan yang baik tetapi mempunyai potensi lemah dalam hal laba. Lebih sedikit persaingan lebih aktratif/ menariklah segmen tersebut untuk dimasuki.

Perusahaan dapat mengikuti salah satu diantara lima strategi peliputan pasar, yaitu (Lubis, 2004):

1) Konsentrasi pasar tunggal, ialah sebuah perusahaan dapat memusatkan kegiatannya dalam satu bagian daripada pasar. Biasanya perusahaan yang lebih kecil melakukan pilihan ini.

2) Spesialisasi produk, sebuah perusahaan memutuskan untuk memproduksi satu jenis produk. Misalnya sebuah perusahaan memutuskan untuk memproduksi hanya mesin tik listrik bagi sekelompok pelanggan.

3) Spesialisasi pasar, misalnya sebuah perusahaan memutuskan untuk membuat segala macam mesin tik, tetapi diarahkan untuk kelompok pelanggan yang kecil.

4) Spesialisasi selektif, sebuah perusahaan bergerak dalam berbagai kegiatan usaha yang tidak ada hubungan dengan yang lainnya, kecuali bahwa setiap kegiatan usaha itu mengandung peluang yang menarik.

5) Peliputan keseluruhan, yang lazim dilaksanakan oleh industri yang lebih besar untuk mengungguli pasar.

Menurut Kasali dalam Fauziah (2016) ada empat yang harus dipenuhi dalam mendapatkan pasar sasaran itu adalah sebagai berikut:

1) Responsif

Pasar sasaran harus responsif terhadap produk atau produk pemasaran yang di kembangkan. Langkah ini dimulai dengan studi segmentasi yang jelas karena tanpa pasar sasaran yang jelas produsen 
menanggung resiko yang terlalu besar.

2) Potensi penjualan

Potensi penjualan harus cukup luas. Semakin besar pasar sasaran, semakin besar nilainya. Besarnya bukan hanya ditemukan oleh jumlah populasi tapi juga daya beli dan keinginan pasar untuk memiliki produk tersebut.

3) Pertumbuhan yang memadai.

Pasar yang tidak dengan segera bereaksi. Pasar tumbuh perlahanlahan sampai akhirnya meluncur dengan cepat dan mencapai titik pendewasaan.

4) Jangkauan Media

Pasar sasaran dapat dicapai dengan optimal kalau pemasar tepat memilih media untuk mempromosikan dan memperkenalkan produknya.

\section{Positioning}

Penempatan produk (positioning) mencakup kegiatan merumuskan penempatan produk dalam persaingan dan menetapkan bauran pemasaran yang terperinci. Pada hakekatnya penempatan produk adalah tindakan merancang produk dan bauran pemasaran agar tercipta kesan tertentu diingatan konsumen (Lubis, 2004). Menurut Soegoto (2009) Positioning adalah cara membangun citra atau identitas di benak konsumen untuk produk, merek, atau lembaga tertentu dengan membangun persepsi relative suatu produk terhadap produk lain. Berdasarkan pengertian positioning menurut beberapa ahli dapat disimpulkan bahwa positioning adalah penempatan produk dengan ciri khas yang dimiliki produk itu sendiri dan mampu bersaing dengan produk yang lain. (Kotler dan Keller,2008) menjelaskan beberapa cara product positioning yang dapat dilakukan pemasar dalam memasarkan produk kepada konsumen yang dituju, antara lain:

a. Penentuan posisi menurut atribut

Hal ini terjadi apabila suatu perusahaan memposisikan dengan menonjolkan atribut produk yang lebih unggul dibanding pesaingnya, seperti ukuran, lama keberadaannya, dan seterusnya. Misalnya Disneyland dapat mengiklankan Disneyland sebagai taman hiburan terbesar di dunia.

b. Penentuan posisi menurut manfaat Hal ini terjadi apabila produk diposisikan sebagai pemimpin dalam suatu manfaat tertentu.

c. Penentuan posisi menurut penggunaan atau penerapan

Seperangkat nilai-nilai penggunaan atau penerapan inilah yang digunakan sebagai unsur yang ditonjolkan dibandingkan pesaingnya, misal: Japanese Deer Park memposisikan diri untuk wisatawan yang hanya ingin memperoleh hiburan singkat.

d. Penentuan posisi menurut pemakai Hal ini berarti memposisikan produk sebagai yang terbaik untuk sejumlah kelompok pemakai. Pasar sasaran lebih ditujukan pada sebuah atau lebih komunitas, baik dalam arti sempit maupun dalam arti luas. Misalnya Magic Mountain dapat mengiklankan diri sebagai taman hiburan untuk 'pencari tantangan'.

e. Penentuan posisi menurut pesaing Produk secara keseluruhan menonjolkan nama mereknya secara utuh dan diposisiskan lebih baik daripada pesaing. Misalnya: Lion Country Safari dapat beriklan memiliki lebih banyak macam binatang jika dibandingkan dengan Japanese Deer Park.

f. Penentuan posisi menurut kategori produk

Produk diposisikan sebagai pemimpin dalam suatu kategori produk.

g. Penentuan posisi harga atau kualitas Produk diposisikan sebagai menawarkan nilai terbaik. Misalnya Busch Gardens dapat memposisikan diri sebagai nilai terbaik untuk harga.

\section{SWOT}

Analisis SWOT (SWOT analysis) yakni mencakup upaya-upaya untuk mengenali kekuatan, kelemahan, peluang, dan ancaman 
yang menentukan kinerja perusahaan. Informasi eksternal mengeni peluang dan ancaman dapat diperoleh dari banyak sumber, termasuk pelanggan, dokumen pemerintah, pemasok, kalangan perbankan, rekan diperusahaan lain. Banyak perusahaan menggunakan jasa lembaga pemindaian untuk memperoleh keliping surat kabar, riset di internet, dan analisis tren-tren domestik dan globalyang relevan(Daft, 2010). Selanjutnya Rangkuti (2004) menjelaskan bahwa Analisis SWOT adalah identifikasi berbagai faktor secara sistematis untuk merumuskan strategi perusahaan. Analisis ini didasarkan pada logika yang dapat memaksimalkan kekuatan (strength) dan peluang (opportunity), namun secara bersamaan dapat meminimalkan kelemahan (weakness) dan ancaman (threats). Proses pengambilan keputusan strategi selalu berkaitan dengan pengembangan misi, tujuan, strategi dan kebijakan perusahaan. Berdasarkan hal tersebut, perencanaan strategi harus menganalisa factor-faktor strategi perusahaan (kekuatan, kelemahan, peluang dan ancaman) dalam kondisi yang saat ini. Analisis SWOT membandingkan antara faktor eksternal peluang (opportunity) dan ancaman (threats) dengan faktor internal kekuatan (strenght) dan kelemahan(weakness).

\section{Metode Penelitian}

\section{A. Pendekatan Penelitian}

Jenis penelitian yang digunakan dalam penelitian ini adalah deskriptif dengan pendekatan kualitatif. Menurut Sugiyono (2012), penelitian deskriptif adalah metode yang digunakan untuk menggambarkan atau menganalisa suatu hasil penelitian. Penelitian yang bersifat deskriptif bertujuan menggambarkan secara tepat sifat-sifat suatu individu, keadaan, gejala, atau kelompok tertentu, untuk menentukan frekuensi adanya hubungan tertentu antara suatu gejala dan gejala lain dalam masyarakat (Mely G. Tan dalam Silalahi, 2009). Penelitian kualitatif adalah penelitian yang dilakukan pada obyek alamiah, di mana realitas sosial dipandang memiliki hubungan gejala bersifat interaktif (Sugiyono, 2016). Jenis penelitian deskriptif dengan pendekatan kualitatif ini akan memberikan gambaran secara mendalam keterkaitan antara data atau fakta mengenai segmentation, Targetting, dan positioning kopi Karlos sebagai strategi pemasaran.

\section{B. Lokasi dan Situs Penelitian}

Lokasi penelitian ini di Kabupaten Malang, Kecamatan Karangploso. Situs penelitian yaitu di Desa Donowarih. Desa Donowarih memiliki luas wilayah seluas 2271,188 Ha. Desa Donowarih adalah salah satu Desa yang berada di sebelah barat Kecamatan Karangploso dengan penduduk yang berjumlah sekitar 7.206 jiwa merupakan salah satu desa yang mempunyai penduduk terpadat di kawasan Karangploso, Kabupaten Malang, Provinsi Jawa Timur. Pemanfaatan lahan dari desa ini meliputi pemukiman, lahan persawahan, ladang, perkebunan, hutan dan lain-lain (Septiropa, 2010). Situs penelitian berada di Desa Donowarih karena Desa Donowarih merupakan salah satu daerah di Kabupaten Malang yang memiliki potensi pertanian, khususnya dalam menghasilkan kopi Karlos sebagai brand dari Kecamatan Karangploso(kopiluwakamstirdam.com,2011).

\section{Fokus Penelitian}

Dalam sebuah penelitian tentunya terdapat fokus penelitian, terutama pada penelitian kualitatif. Menurut Moleong (2008) “Masalah dalam penelitian kualitatif bertumpu pada suatu fokus". Fokus penelitian digunakan sebagai pembatasan studi, hal tersebut dilakukan agar sebuah penelitian tetap fokus dan tidak terlalu melebar. Fokus dari penelitian ini sebagai berikut:

1. Segmentation

a. Segmentasi demografik

b. Segmentasi psikografik

2. Targetting

a. Potensi penjualan

b. Pertumbuhan yang memadai

3. Positioning

a. Atribut

b. Manfaat

c. Pesaing

d. Produk

e. Harga/kualitas

4. SWOT 


\section{Sumber Data}

Sumber data terdiri dari sumber data primer dan sumber data sekunder (Silalahi, 2009).

1. Data Primer

Menurut Silalahi (2009), data primer adalah data yang didapatkan dari situasi aktual. Data primer diperoleh secara langsung melalui observasi di Desa Donowarih dan wawancara dengan tengkulak kopi Karlos, pengelola kopi, dan kedai kopi D.W. Coffee.

2. Data Sekunder

Data sekunder adalah data yang dikumpulkan dari sumber-sumber lain sebelum penelitian dilakukan (Silalahi, 2009). Data sekunder diperoleh dari penelitian-penelitian terdahulu, jurnal, BPS, dan data pendukung yang berkaitan dengan topik penelitian.

\section{E. Teknik Pengumpulan Data}

Metode pengumpulan data merupakan cara yang digunakan untuk mengumpulkan atau mendapatkan data dari fenomena secara empiris (Silalahi, 2009). Teknik pengumpulan data yang digunakan oleh peneliti terdiri dari:

1. Wawancara, yaitu peneliti melakukan tanya-jawab dengan tengkulak kopi Karlos, pengelola kopi, dan pemilik kedai kopi D.W. Coffee sebagai informan untuk mendapatkan informasi atau data yang diperlukan.

2. Observasi, yaitu peneliti melakukan pengamatan di lokasi penelitian dan pada kegiatan yang dilakukan oleh sumber data

3. Dokumentasi, peneliti menggunakan tulisan-tulisan sebagai bagian dari data.

\section{F. Uji Kredibilitas}

\section{Triangulasi Sumber}

Triangulasi sumber adalah pengujian kredibilitas data dengan cara mengecek data yang telah diperoleh melalui beberapa sumber (Sugiyono, 2016: 273274). Peneliti melakukan triangulasi sumber data melalui tiga informan, yaitu tengkulak kopi, pengelola kopi, dan pemiliki kedai kopi D.W. Coffee.

2. Triangulasi Teknik

Triangulasi teknik untuk menguji kredibilitas data dilakukan dengan cara mengecek data kepada sumber yang sama dengan teknik yang berbeda (Sugiyono, 2016: 274). Peneliti melakukan triangulasi teknik dengan tiga cara, yaitu wawancara, observasi, dan dokumentasi.

3. Triangulasi Waktu

Triangulasi waktu dilakukan untuk memperoleh data yang lebih valid dengan melakukan pengumpulan data berdasarkan waktu yang berbeda (Sugiyono, 2016: 274).

\section{G. Instrumen Penelitian}

Instrumen penelitian yang digunakan, yaitu:

1. Peneliti, karena peneliti melakukan wawancara, dokumentasi, dan observasi

2. Interview Guide untuk tiapinforman, pedoman observasi, pedoman dokumentasi, dan buku catatan lapangan digunakan untuk membatasi dan mengarahkan peneliti dalam mencati data-data yang diperlukan sesuai dengan fokus penelitian.

3. Alat perekam, alat komunikasi, dan buku catatan digunakan saat observasi dan wawancara serta sebagai alat pengumpul data.

\section{H. Metode Analisis}

Penelitian ini menggunakan metode analisis model Miles, Huberman, dan Saldana. Menurut Miles, Huberman dan Saldana (2014), terdapat tiga alur kegiatan yang terjadi secara bersamaan dalam analisis data kualitatif. Analisis data kualitatif tersebut yaitu kondensasi data (data condensation), sajian data (data display), dan penarikan simpulan (conclusion drawing).

Menurut Miles, Huberman, dan Saldana, terdapat beberapa tahapan yang harus digunakan dalam metode analisis data kualitatif, yaitu (Lestari, 2015):

1. Kondensasi data (Data condensation)

Kondensasi data merupakan proses memilih, menyederhanakan, mengabstrakkan, dan mentransformasikan data yang mendekati keseluruhan bagian dari catatan-catatan lapangan secara tertulis, hasil wawancara, dokumen-dokumen, dan artikel-artikel terkait.

2. Penyajian data (Data display)

Penyajian data adalah pengorganisasian, penyimpulan, dan penyatuan informasi yang memungkinkan. Penyajian data 
membantu untuk memahami apa yang terjadi, termasuk analisis yang lebih dalam.

3. Penarikankesimpulan(Conclusion drawing) Penarikan kesimpulan dilakukan dengan mencari keteraturan pejelasan, konfigurasikonfigurasi yang memungkinkan, alur sebab-akibat, dan proposisi.

\section{Hasil dan Pembahasan}

\section{A. Gambaran Umum}

Indonesia merupakan negara penghasil kopi dalam jumlah yang banyak, perkebunan kopi tersebar di seluruh wilayah Indonesia dengan khasnya masing- masing. Salah satu yang memiliki potensi besar dalam perkebunan kopi adalah Kecamatan Karangploso kabupaten Malang dengan komoditi unggulan kopi jenis Arabika, penopang utama dalam memproduksi kopi terletak di Desa Donowarih yang merupakan salah satu Desa yang terkenal sebagai penghasil kopi di Kecamatan Karangploso dengan brand kopi Karlos.Kopi Karlos memiliki rasa yang berbeda dengan kopi pada umumnya, kopi inimemiliki tingkat keasaman yang mendekati jeruk nipis dengan akhir rasa coklat yang tertinggal cukup lama (kopiluwakamstirdam.com).

Keadaan topografi Desa Donowarih memiliki ketinggian 1100 -1200 dpl serta suhu $16^{\circ} \mathrm{C}-20^{\circ} \mathrm{C}$ cocok untuk digunakan menanam kopi, jenis kopi yang ditanam di Desa Donowarih adalah kopi Arabica dengan varietas lini S dan cobra 790 (berdasarkan observasi peniliti). Dengan varietas yang unggul dan teknik pengolahan kopi yang benar menghasilkan kopi yang berbeda dengan kopi unggulan daerah lainnya. Jenis kopi yang dihasilkan di Kecamatan Karang Ploso : kopi natural, kopi full wash, kopi semi full wash, dan kopi honey, kopi tersebut berasal dari varietas yang sama aka tetapi memiliki cita rasa yang berbeda, hal yang membedakannya terletak pada proses pengolahan kopi (hasil dari observasi). Kopi Karlos sendiri banyak sekali peminatnya kebanyakan kedai kopi Malang menggunakan kopi Karlos selain itu kopi Karlos juga di pasarkan ke kota lain seperti di Bandung, di Bandung sendiri terdapat lima kedai kopi yang menggunakan produk kopi Karlos (berdasarkan sumber hasil wawancara dengan Bapak Muji pengelola kopi Karlos).

Pemasaran biji kopi Karlos masih bisnis to bisnis (B2B) sehinga yang membeli biji kopi Karlos kedai - kedai kopi atau café. Pemasaran biji kopi Karlos yang bisnis to bisnis membuat pasar biji kopi Karlos sempit, meskipun sempit karena hanya menjual biji kopi kepada kedai - kedai kopi dan café karena biji kopi yang di jual masih butuh proses finishing yang membutuh peralatan untuk penyanggraihan kopi dan penghasulan kopi agar biji kopi bisa dinikmati oleh penikmat kopi. Meskipun sempit pemasarannya bukan berarti lebih mudah dalam pengelolaanya, karena dibutuhkan hubungan yang baik antara pemasok dan pelanggan bisnis sehingga tercipta keunggulan kompetitif yang berkesinambungan dalam rangka membangun dan menciptakan loyalitas pelanggan. Strategi pemasaran pada bisnis to bisnis, para bisnis tidak melakukan pembelian karena nilai emosional tetapi cenderung bersifat rasional. Pelanggan bisnis to bisnis lebih memperhatikan komponen harga dan kualitas serta fungsi yang ditawarkan oleh suatu produk, selain nilai fungsional. Karena konsumsi kopi dosmetik terus meningkat dibandingkan dengan ekspor biji kopi maka diperlukan strategi pemasaran yang tepat agar menjadikan biji kopi Karlos bertahan di pasaran. Pendekatan strategi pemasaran dengan menggunakan analisis Strenght, Targetting, Positioning (STP) dan metode analisis SWOT akan membantu dalam pemasaran biji Karlos, sehingga mampu meningkatkan kesejahteraan petani kopi Karlos di Desa Donorawih Kecamatan Karang Ploso karena dengan meningktanya permintaan kopi Karlos maka akan meningkatkan jumlah produksi kopi Karlos serta meningkatkan harga jual kopi Karlos.

\section{B. Penyajian Data}

\section{Segmentation}

Menurut Fandy Tjipjono (dalam analisis segmentasi literature 2001) segmentasi pasar adalah proses membagi pasar keseluruhan suatu produk atau jasa yang bersifat heterogen ke dalam 
beberapa segmen, di mana masing masing segmennya cenderung bersifat homogeny dalam segala aspek. Weinstein, Malcom \& Ian Dunbar, Rao \& Steckel dan Stanton, Etzel dan Walker mendefiniskan segmentasi adalah proses pembagian pasar ke dalam kelompok kelompok berdasarkan kesamaan kebutuhan atau karakteristik yang serupa dalam perilaku pembelian konsumen. Terdapat empat variabel utama yang mungkin dipergunakan dalam mensegmentasi pasar konsumen. Namun, dalam penelitian ini hanya terdapat dua variabel yaitu:

a. Segmentasi Demografik

Segmentasi demografik membagi pasar menjadi kelompok berdasarkan pada variabel seperti umur, jenis kelamin, besar keluarga, siklus kehidupan keluarga, pendapatan, pekerjaan, pendidikan, agama, ras, dan kebangsaan. Untuk kopi Karlos sendiri kebanyakan peminatnya adalah mahasiswa dan berjenis kelamin cowok. Seperti kata salah satu narasumber kami

"Untuk di kedai ini rata rata mahasiswa, karena memang segmentasi yang paling besar adalah mahasiswa, mayoritas cowok lebih dominan.."

Selain itu, Manager Kedai Kopi After Taste juga mengatakan kebanyakan peminat kopi Karlos berasal dari menengah bawah.

“Untuk penikmat kopi Karlos lebih menengah kebawah, karena kopi Karlos tidak terlalu mahal. Dari penyajian juga berbeda beda kalau untuk kopi Karlos lebih ke single origin (tanpa ada campuran sesuatu)."

"Saat ini jumlah penikmat kopi Karlos tahun ini meningkat, permintaan penikmat kopi Karlos juga meningkat, dan juga kopi kopi lokal selain Karlos juga sedang naik daun. Penikmat kopi mulai menemukan titik jenuh, dan ketertarikan penikmat kopi lokal lebih besar."
Hal ini juga diperkuat dengan pernyataan bapak Arumtaba yang merupakan konsumen kopi Karlos dan bekerja sebagai dosen farmasi UMM, dengan pernyataan sebagai berikut:

"Sama saja sih mas, nggak terlalu murah dan juga nggak terlalu mahal"

Berdasarkanpenyataannarasumber diatas segmentasi demografis yang diciptakan oleh produsen kopi Karlos adalah mahasiswa dan berjenis kelamin laki-laki.

b. Segmentasi Psikografik

Segmentasi psikografik membagi pembeli menjadi kelompok berbeda berdasarkan pada karakteristik sosial, gaya hidup atau kepribadian. Seperti yang dikatan bapak arumtaba bahwasanya ia meminum kopi Karlos tergantung keinginanya

“Kalau saya ya karena memang penikmat kopi, kalau untuk jenis kopi yang saya konsumsi sih ya tergantung keinginannya kopi apa, kadang kadang Karlos, kadang kadang Gayo, macam macam lah. Kalau Karlos ya memang yang berbeda itu rasanya itu mas"

Selain itu tak jarang orang ingin meminum kopi Karlos karena penasaran dengan rasanya yang berbeda dengan kopi pada umumnya. seperti yang dikatakan oleh manager after taste.

"...... Untuk honeey rasanya lebih asem buah dan untuk yang natural lebih seger...."

Narasumber kami lainya juga mengatakan memang kopi Karlos memiliki rasa yang berbeda

"Gimana ya, kalau menurut saya ya dari rasanaya itu kayak apel kecut kecut gimana gitu. Beda dengan kopi Gayo, kalau Gayo itu lebih kayak ada rempah nya."

\section{Targetting}

Targetting merupakan proses mengevaluasi dan memilih satu atau beberapa segmen pasar yang dinilai paling menarik untuk dilayani dengan program pemasaran spesifik perusahaan (Fandy 
Tjiptono, 2012). Menurut Kasali dalam Fauziah (2016) ada empat yang harus dipenuhi dalam mendapatkan pasar sasaran, namun dalam penelitian ini terdapat dua hal yang dipakai sesuai dengan hasil wawancara di lapangan. Ketiga hal tersebut yaitu:

a. Potensi Penjualan

Pasar sasaran harus responsif terhadap produk atau produk pemasaran yang di kembangkan. Langkah ini dimulai dengan studi segmentasi yang jelas karena tanpa pasar sasaran yang jelas produsen menanggung resiko yang terlalu besar. Semakin besar pasar sasaran, semakin besar nilainya. Besarnya bukan hanya ditemukan oleh jumlah populasi tapi juga daya beli dan keinginan pasar untuk memiliki produk tersebut. Peminat kopi Karlos sendiri tahun ini semakin meningkat sesuai perkataan dari manager Kedai Kopi After Taste

"Saat ini jumlah penikmat kopi Karlos tahun ini meningkat, permintaan penikmat kopi Karlos juga meningkat, dan juga kopi kopi lokal selain Karlos juga sedang naik daun. Penikmat kopi mulai menemukan titik jenuh, dan ketertarikan penikmat kopi lokal lebih besar."

Selain itu manager Kedai Kopi After Taste juga mengakui bahwa tahun ini kualitas kopi Karlos semakin membaik, seperti yang dikata di bawah ini :

"Untuk tahun ini kualitas kopi Karlos lebih bagus, kalau diolah juga lebih konsisten. Karakter kopi Karlos lebih menonjol asem sitrus lebih seger. Kalau diseduh dengan metodeyang berbeda rasanya juga berbeda. Misalnya dengan pokis rasanya lebih pekat dan teksturnya encer. Kalau tubruk bodinya lebih seperti kopi biasa. Metode yang beda, daya tariknya juga berbeda."

Pernyataan tersebut diperkuat oleh perkataan bapak Raja selaku pemilik Kedai Kopi Amstirdam
"Sekarang kopi lagi high jadinya banyak yang penasaran. Kalo dari segi rasa dibandingkan dengan kopi luar kalah jauh, jauh banget'

Berdasarkan hal yang disampaikan oleh narasumber dapat diketahui diketahui jika kopi Karlos dewasa ini mengalami peningkatan peminat namun dilain sisi hal ini juga menjadi tantangan untuk para produsen agar mampubertahan dipasaran.

b. Pertumbuhan yang memadai

Pasar yang tidak dengan segera bereaksi. Pasar tumbuh perlahan-lahan sampai akhirnya meluncur dengan cepat dan mencapai titik pendewasaan. Manager Kedai Kopi After Taste mengatakan bahwa ada pesaing dalam memasarkan kopi Karlos

"Ada sih, yang menyaingi, seperti kopi arjuno Kopi Karlos merupakan brand dari daerah lokal dari karangploso yang ditanam di lereng gunung arjuno. Cuman belum ada yang menemukan variable atau nilai yang sama dengan kopi Karlos".

Manager kedai after taste juga mengatakan kekurangan dari penjualan kedai ini adalah harganya yang tergantung biaya pengiriman.

"Sebenarnya harga bahan baku tidak terlalu mahal dan tidak terlalu murah. Untuk semuanya sama, tergantung biaya pengirimannya. Kalau ke luar jawa memang lebih besar, perbandingannya adalah kualitas, ada grade 1, grade 2"

Selain itu, Narasumber kami lainya yang merupakan pemilik dari kedai kopi Amstirdam juga mengatakan permasalahan yang dihadapi dalam pengolahan kopi Karlos, berikut pertnyataan:

"Problemnya itu diproses pengolahannya beda beda. jadi Cuma full wash sama semiwash. Jadi Cuma full wash atau semiwash. Kalo disini kan petaninya kebingungan jadi mereka coba semua teknik. Kalo di Etiopia itu Cuma pake satu teknik. Kalo dari Karlos kemaren 


\section{Positioning}

\author{
ini sebenernya. ${ }^{\prime \prime}$ \\ Oleh karena ini diperlukan \\ inovasi untuk mengatasi hambatan \\ hambatan diatas, agar kopi Karlos \\ mampu terus bersaing dan lebih \\ dikenal masyarakat luas.
}

Menurut Eddy Soeryanto Soegoto (2009) Positioning adalah cara membangun citra atau identitas di benak konsumen untuk produk, merek, atau lembaga tertentu dengan membangun persepsi relative suatu produk terhadap produk lain. Berdasarkan pengertian positioning menurut beberapa ahli dapat disimpulkan bahwa positioning adalah penempatan produk dengan ciri khas yang dimiliki produk itu sendiri dan mmapu bersaing dengan produk yang lain.

a. Atribut

Hal ini terjadi apabila suatu perusahaan memposisikan dengan menonjolkan atribut produk yang lebih unggul dibanding pesaingnya, seperti ukuran, lama keberadaannya, dan seterusnya. Kopi Karlos sendiri memiliki keunikan rasa yang sudah diakui seperti yang dikatakan manager kadai after taste

"Yang membedakan adalah prosesnya, dari hasil panen terus di proses sudah beda. Hasil akhirpun diseduh rasanya juga beda. Untuk honey rasanya lebih asem buah dan untuk yang natural lebih seger."

Hal ini juga disetujui oleh bapak Arumtaba selaku konsumen kopi Karlos yang mengatakan bahwa :

"...Kalau Karlos ya memang yang berbeda itu rasanya itu mas...."

Selain itu beliau juga mengatakan "Waduh, kalau itu mas ya tergantung orang nya. Gimana ya, kalau menurut saya ya dari rasanaya itu kayak apel kecut kecut gimana gitu. Beda dengan kopi Gayo, kalau Gayo itu lebih kayak ada rempah nya"

Oleh sebab itu sebenarnya kopi Karlos sudah memiliki branding yang bagus untuk lebih dikenal dan berkembang di masyarakat. b. Manfaat

Hal ini terjadi apabila produk diposisikan sebagai pemimpin dalam suatu manfaat tertentu. Untuk hal tersebut, keunikan dari rasa kopi Karlos merupakan daya tarik utama konsumen seperti kata bapak raja selaku pemilik Kedai Kopi Amstirdan.

"rasa mungkin rasa. kopi sejuk itu? Jadi, potensi kopi itu diukur dari rasa yang keluar itu apa aja, ambilno mecca. Kopi ini dari Kenya. dari kopi ini saya bisa cerita Kopi ini punya big personality ada rasa buah yang sudah mateng dia ini punya sweet benar benar manis banget kopinya dibanding gula kayak buah. Ada honey madu, jus jeruk sama apricot. Kita bisa cerita dari kopi ini, kita ada yang disana itu tadi e ada jeruknya sama jasmint ada caramel. Jadi dia bisa cerita. Apa yang terjadi di Karlos kan kopinya ini dijual secara komersial. Masuk ke pabrik kopi jadi kopi sachet. Kita mau ngenalin generasi ketiga kopi. Kopi itu punya karakter. Itu jeruk nipis coklat Pas di Jakarta dibandingin kopi dari luar itu"

Selain itu, menurut Narasumber kami lainnya yang merupakan manager Kedai Kopi After Taste mengatakan bahwa para konsumen sudah mulai mengalami titik jenuh sehingga lebih tertatik pada jenis kopi lokal. Seperti pernyataannya sebagai berikut ;

"Saat ini jumlah penikmat kopi Karlos tahun ini meningkat, permintaan penikmat kopi Karlos juga meningkat, dan juga kopi kopi lokal selain Karlos juga sedang naik daun. Penikmat kopi mulai menemukan titik jenuh, dan ketertarikan penikmat kopi lokal lebih besar."

Dari hal tersebut diketahui jika daya tarik utama konsumen kopi Karlos adalah rasanya yang unik dan tiada duanya. 
c. Pesaing

Produk secara keseluruhan menonjolkan nama mereknya secara utuh dan diposisiskan lebih baik daripada pesaing. Menurut manger dari kedai Kopi After Taste ada beberapa pesaing dalam memasarkan Kopi Karlos.

"Ada sih, yang menyaingi, seperti kopi arjuno Kopi Karlos merupakan brand dari daerah lokal dari Karangploso yang ditanam di lereng gunung Arjuno. Cuman belum ada yang menemukan variable atau nilai yang sama dengan kopi Karlos"

Hal tersebut disetujui oleh bapak raja selaku pemilik Kedai Kopi Amstirdam yang mengatakan:

"sebenarnya kalo saingan itu banyak. Itu Selekta, Pujon, dari Pujon itu, dari Selekta ada satu yang bagus banget e anak anak yang ngerti kopi, e gunung Semeru ini juga lagi garap arabika. Umurnya sama kayak Karlos. Semua hampir semua gunung ada. Di Kediri ada proyeknya Bank Indonesia, mereka sudah menanam 300.000 bibit kopi. Di Kediri dan Tulungagung saya dapat samplenya. Jadi setiap daerah itu. Jadi nanti siapa yang mampu memimpin rasa dan kualitas. Itu dia yang menang"

Banyaknya pesaing tersebut, para produsen memerlukan inovasi dan srategi agar Kopi Karlos mampu menyesuaikan dengan perkembangan sehingga tidak kalah saing tidak hilang dipasaran.

d. Produk

Produk diposisikan sebagai pemimpin dalam suatu kategori produk. Kopi Karlos menawarkan rasa yang berbeda dengan kopi pada umumnya seperti kata Bapak Arumtaba selaku konsumen Kopi Karlos, sebagai beriku:

"Gimana ya, kalau menurut saya ya dari rasanya itu kayak apel kecut kecut gimana gitu. Beda dengan kopi Gayo, kalau Gayo itu lebih kayak ada rempah nya."
Hal ini juga di perkuat oleh pernyatan bapak Raja tentang banyaknya varian rasa kopi Karlos yang unik dan tidak terdapat pada kopi Karlos umumnya

"Ada honey madu, jus jeruk sama apricot. Kita bisa cerita dari kopi ini, kita ada yang disana itu tadi ada jeruknya samajasmin ada caramel."

Selain itu harga kopi Karlos juga terjangkau seperti pernyataan bapak Arumtaba selaku konsumen kopiKarlos di Kedai Kopi Amstirdam

" Sama saja sih mas, nggak terlalu mahal dan juga nggak terlalu murah."

Jadi tak heran jika banyak mahasiswa yang suka dengan kopi Karlos seperti yang dikatakan manager Kedai Kopi After Taste

" Untuk di kedai ini rata rata mahasiswa, karena memang segmentasi yang paling besar adalah mahasiswa."

Berdasarkan pernyataan pernyataan di atas dapat disimpulkan jika kopi Karlos memiliki banyak keunggulan mulai dari rasanya yang unik hingga harganya yang terjangkau.

e. Harga

Produk diposisikan sebagai menawarkan nilai terbaik. Untuk harganya sendiri kopi Karlos bukanlah termasuk kopi mahal, seperti yang di katakanManagerKedaiKopi After Taste yangmengatakan:

“ Untuk penikmat kopi Karlos lebih menengah kebawah, karena kopi Karlos tidak terlalu mahal. Dari penyajian juga berbeda beda kalau untuk kopi Karlos lebih ke single origin (tanpa ada campuran sesuatu)."

Hal ini selaras dengan pernyataan bapak Arumtaba selaku konsumen kopi Karlos di Kedai Kopi Amstirdam

"Sama saja sih mas, nggak terlalu mahal dan juga nggak terlalu murah." 
Sehingga hal tersebut dapat disimpulkan jika harga kopi Karlos masih dapat dijangkau semua kalangan. Apalagi kebanyakan pelanggan juga merupakan mahasiswa seperti yang di katakan Manager Kedai Kopi After Taste:

"Untuk di kedai ini rata rata mahasiswa, karena memang segmentasi yang paling besar adalah mahasiswa."

\section{SWOT}

Menurut Freddy Rangkuti (2009: 18) Analisis SWOT adalah identifikasi berbagai faktor secara sistematis untuk merumuskan strategi perusahaan. Analisis ini didasarkan pada logika yang dapat memaksimalkan kekuatan (Strengths) dan peluang (Opportunities), namun secara bersamaan dapat meminimalkan kelemahan (Weaknesses) dan ancaman (Threats).

\section{a. Strengths}

Kekuatan adalah sumber daya, keterampilan, atau keungulan keungulan lain yang berhubungan dengan para pesaing perusahaan dan kebutuhan pasar yang dapat dilayani oleh perusahaan yang diharapkan dapat dilayani. Kekuatan adalah kompetisi khusus yang memberikan keunggulan kompetitif bagi perusahaan di pasar. Keunggulan dari kopi Karlos adalah prosesnya yang benar benar di perhatikan sehingga menghasilkan kopi berkualitas dan berbeda dari kopi kebanyakan, seperti yang dikatakan bapak raja pemilikKedai kopi Amstirdam

"Karlos punya. Eh, apa yang, apa kesalahan yang dilakukan oleh petani itu bisa kita ketahui waktu penggorengan. Sedangkan potensinya....Nggoreng ini kan bukan sekedar nggoreng tapi ada seninya. Itu yang selama ini kita lakukan. Fermentasi kelebihan 1 jam, bisa membedakan rasa. Metik belum merah rasanya juga beda. Ukuran ndak seragam, rasanya juga beda. Ada yg besar ada yang kecil, matengnya kan beda, tapi kalo disamakan nantinya rasanya beda-beda.

b. Weakness

Kelemahan adalah keterbatasan atau kekurangan dalam sumber daya, keterampilan, dankapabilitasyang secara efektif menghambat kinerja perusahaan. Keterbatasan tersebut dapat berupa fasilitas, sumber daya keuangan, kemampuan manajemen dan keterampilan pemasaran dapat meruoakan sumber dari kelemahan perusahaan. Untuk penjualan kopi Karlos masalah utama adalah dalam proses. Seperti yang di katakan oleh bapak raja selaku pemilik Kedai Kopi Amstirtam

"problemnya itu di ini, proses kopi itu macem macem kalau buat punya kadar gula tinggi, dia itu kopinya tidak perlu di proses lagi. Dia Cuma di full wash atau semi wash itu sudah cukup untuk mengelurkan semua rasa. Disini itu petani masih kebingungan makana mereka nyobain semua cara. Di etiopia itu dia itu Cuma punya satu kopi item, dia Cuma ada natural aja tidak ada fullwash tidak ada semiwash. Di Kenya, dia itu punya cara fermentasi sendiri di Sumatra kebanyakan di giling basah, jadi setiap tempat itu mestinya dia mulai cari koleksi . Kalo dari Karlos ini sebenernya ada wash honey, ada black hone, ada apa honey, tapi rasana sama semua. Percuma to dibuat macem macem kalo rasanya sama semua. Pernah denger'

c. Opportunities

Peluang adalah situasi penting yang mengguntungkan dalam lingkungan perusahaan. Kecendrungan - kecendrungan penting merupakan salah satu sumber peluang, seperti perubahaanteknologidanmeningkatnya hubungan antara perusahaan dengan pembeli atau pemasokk merupakan gambaran peluang bagi perusahaan. Kopi Karlos mempu 
memberikan rasa yang unik dan berbeda dengan kopi pada umumnya seperti pernyataan bapak Arumtaba selaku Konsumen

"Waduh, kalau itu mas ya tergantung orang nya. Gimana ya, kalau menurut saya ya dari rasanaya itu kayak apel kecut kecut gimana gitu. Beda dengan kopi Gayo, kalau Gayo itu lebih kayak ada rempah nya."

Hal ini juga diperkuat oleh pernyataaan Manager Kedai Kopi After Taste sebagai berikut

"Saat ini jumlah penikmat kopi Karlos tahun ini meningkat, permintaan penikmat kopi Karlos juga meningkat, dan juga kopi kopi lokal selain Karlos juga sedang naik daun. Penikmat kopi mulai menemukan titik jenuh, dan ketertarikan penikmat kopi lokal lebih besar."

d. Threats

Ancaman adalah situasi penting yang tidak menguntungan dalam lingkungan perusahaan. Ancaman merupakan pengganggu utama bagi posisi sekarang atau yang diinginkan perusahaan. Adanya peraturan-peraturan pemerintah yang baru atau yang direvisi dapat merupakan ancaman bagi kesuksesan perusahaan. Ancaman utama dalam kopi Karlosa adalah banyaknya pesaing dalam pasaran yang memiliki branding lebih baik seperti pernyataan bapak raja sebagai berikut:

"sebenarnya kalo saingan itu banyak. Itu selekta, pujon, dari pujon itu, dari selekta ada satu yang bagus banget e anak anak yang ngerti kopi, e gunung Semeru ini juga lagi garap arabika. Umurnya sama kayak Karlos. Semua hampir semua gunung ada. Di Kediri ada proyeknya bank Indonesia, mereka sudah menanam 300.000 bibit kopi. Di Kediri dan Tulungagung saya dapat samplenya. Jadi setiap daerah itu. Jadi nanti siapa yang mampu memimpin rasa dan kualitas. Itu dia yang menang"

Hal ini di perkuat oleh pernyataan Manager Kedai Kopi Amstirdam yang mengatakan :

"Ada sih, yang menyaingi, seperti kopi arjuno Kopi Karlos merupakan brand dari daerah lokal dari karangploso yang ditanam di lereng gunung arjuno. Cuman belum ada yang menemukan variable atau nilai yang sama dengan kopi Karlos".

\section{Analisis Data}

\section{Segmentasi}

a. Segmentasi Demografik

Segmentasi demografik membagi pasar menjadi kelompok berdasarkan pada variabel seperti umur, jenis kelamin, keluarga besar, siklus kehidupan keluarga, pendapatan, pekerjaan, pendidikan, agama, ras, dan kebangsaan. Faktorfaktor demografik merupakan dasar paling populer untuk ,dan tingkat penggunaan seringkali amat dekat dengan variabel demografik. Alasan lain adalah variabel demografik lebih mudah diukur ketimbang tipe variabel yang lain. Segmentasi demografik kopi Karlos lebih dominan berjenis kelamin laki - laki. Hal ini diperkuat oleh tingkat konsumsi kopi Karlos yang paling banyak peminatnya adalah berjenis kelamin laki - laki. Secara umum, memang kopi sendiri diminati oleh laki - laki.

Adapun klasifikasi kopi Karlos berdasarkan demografik adalah kalangan mahasiswa dan para konsumen rumah tangga biasa. Kalangan mahasiswa memilih kopi Karlos karena mereka lebih suka menghabiskan waktu luang mereka untuk ngobrol dan meminum kopi di kedai. Selain itu, para konsumen rumah tangga juga sering mengkonsumsi kopi Karlos dengan hanya membeli bijiannya saja dari kedai. Kebanyakan mereka mempunyai alat roasting sendiri di rumah. Permintaan kopi akrlos 
lebih banyak dai konsumen rumah tangga, yang juga lebih dominan berjenis kelamin laki laki yang berumur kisaran 25 - 40 tahun. Konsumen kopi Karlos lebih ditujukan ke kalangan menengah kebawah. Bukan karena harganya yang mahal, tetapi mereka lebih suka dengan cara penyeduhan kopi. Semakin cara mereke menyeduh kopi yang komplek berarti menujukkan derajat sosial konsumen. Dari segi hargapun, kopi Karlos juga tidak terlalu mahal dan murah.

b. Segmentasi Psikografik

Segmentasi psikografik membagi pembeli menjadi kelompok berbeda berdasarkan pada karakteristik sosial, gaya hidup atau kepribadian. Orang yang berada dalam kelompok demografik yang sama dapat saja mempunyai ciri psikografik berbeda. Keberbedaan tersebut tergantung pada kebutuhan dan keinginan seseorang. Berdasarkan kondisi psikografik seseorang yang mengkonsumsi Kopi Karlos, mereka hanya mengikuti selera kopi yang akan mereka konsumsi. Selera konsumen tidak bisa dijadikan sebagai tolok ukur dalam psikografik seseorang. Kopi Karlos juga belum dijadikan kopi favorit pelanggan. Masih beberapa konsumen yang hanya sekadar menginginkan Kopi Karlos untuk dikonsumsi. Dari segi rasapun juga memengaruhi peminat dari Kopi Karlos. Jenis Kopi Karlos yang sering diminati adalah jenis Honey yang memiliki rasa yang akhirannya kecut. Jenis hooney memiliki karakteristik yang mulai paling diminati oleh orang.

\section{Targetting}

Targetting atau menetapkan target adalah persoalan bagaimana memilih, menyeleksi, dan menjangkau pasar. Sehingga produsen lebih mudah untuk memilih pasar dan meningkatkan penjualan. Sedangkan Targetting menurut Keegan \&
Green (2008) adalah proses pengevaluasian segmentasi dan pemfokusan strategi pemasaran pada sebuah negara, propinsi, atau sekelompok orang yang memiliki potensi untuk memberikan respon. Target pasar dapat juga diartikan sebagai kegiatan yang berisi dan menilai serta memilih satu atau lebih segmen pasar yang akan dimasuki oleh suatu perusahaan.

Menurut Kasali dalam Fauziah (2016) ada empat yang harus dipenuhi dalam mendapatkan pasar sasaran, namun dalam penelitian ini yang digunakan hanya tiga. Hal tersebut karena sesuai dengan hasil wawancara di lapangan. Ketiga hal tersebut adalah:

a. Potensi penjualan

Potensi penjualan adalah seberapa luas produk dapat menjangkau pasar. Besarnya bukan hanya ditemukan oleh jumlah populasi tapi juga daya beli dan keinginan pasar untuk memiliki produk tersebut. Untuk peminat kopi Karlos tahun ini semakin meningkat, hal ini juga seiring dengan peningkatan kualitas kopi Karlos yang semakin meningkat, baik dari segi rasa dan tekstur. Namun dilain pihak juga banyak bermunculan pesaing yang menjadi tantangan untuk kopi Karlos untuk tetap mampu bersaing dan bertahan dipasaran.

b. Pertumbuhan yang memadai

Pertumbuhan yang memadai dapat diartikan sebagai reaksi pasar terhadap produk yang diluncurkan. Pasar yang tidak dengan segera bereaksi. Pasar tumbuh perlahanlahan sampai akhirnya meluncur dengan cepat dan mencapai titik pendewasaan.

\section{Positioning}

Positioning adalah penempatan produk dengan ciri khas yang dimiliki produk itu sendiri dan mampu bersaing dengan produk yang lain, seperti yang dikemukakan Lubis (2014) Penempatan produk (positioning) mencakup kegiatan merumuskan penempatan produk dalam persaingan dan menetapkan bauran 
pemasaran yang terperinci. Menurut Kotler dan Keller (2008) menjelaskan beberapa cara product positioning yang dapat dilakukan pemasar dalam memasarkan produk kepada konsumen yang dituju, antara lain:

a. Atribut

Atribut adalah bagaimana suatu perusahaan menempatkan produknya lebih unggul dibandingkan dengan yang lain. Atribut ini juga sebagai salah satu hal dianggap sebagai kekuatan atau ciri khas dari produk tersebut. Bentuk atribut dari kopi Karlos ini adalah terletak pada proses pengolahannya. Proses pengolahan kopi Karlos berbeda dengan kopi lainnya. Hasil dari proses kopi Karlos ini asam sehingga membuat penikmat kopi Karlos berasa lebih puas.

b. Manfaat

Manfaat merupakan dimana produk tersebut memiliki manfaat tersebut bagi pengguna produk tersebut. Manfaat yang ditawarkan kopi Karlos sendiri terlihat pada proses pengolahannya. Karena tanpa menggunakan gula kopi Karlos sendiri sedah memiliki rasa yang enak. Selain itu, kopi Karlos juga memiliki rasa yang berbeda karena rasanya unik. Selain itu konsumen tertarik dengan kopi Karlos tertarik karena mulai bosan dengan kopi luar dan konsumen lebih tertarik dengan kopi lokal.

c. Pesaing

Pesaing adalah bagaimana produk tersebut terlihat menonjol secara utuh dibandingkan dengan kelompok lain. Kopi Karlos ini menonjolkan produknya dengan tetap menjaga kualitasnya dan menomor duakan harga. Menurut produsen kopi Karlos beberapa pesaing yang menjual kopi dibawah harga kopi Karlos tetapi tidak menjaga kualitasnya, tetapi kopi Karlos lebih menjaga kualitasnya sehingga dengan begitu pelanggan akan tetap setia dengan kopi Karlos. Selain itu karena penikmat kopi juga memiliki rasa yang sensitif. Sehingga apabila kopi Karlos sedikit berubah rasa maka konsumen akan berpindah ke kopi yang lain.

d. Produk

Produk adalah bagaimana produk tersebut terlihat lebih unggul di produk lainnya, sehingga produk tersebut bisa memimpin di pasar. Penempatan produk kopi Karlos disini yaitu dengan menawarkan berbagai varian yang didapatkan dari proses pengolahannya. Varian yang terdapat kopi Karlos ini terdapat honey madu, jus jeruk dan apricot. Varian tersebut memiliki rasa yang berbeda, unik dan baru dibandingkan dengan kopi lainnya. Sehingga banyak konsumen kopi yang tertarik dengan kopi Karlosini.

e. Harga

Harga adalah bagaimana produk menawarkan nilai terbaik yang dimilikinya. Kopi Karlos ini memiliki harga dibawah rata-rata. Meskipun memiliki harga dibawah rata-rata namun kopi Karlos ini tetap menjaga kualitas dengan baik. Namun, konsumen tidak terlalu mementingkan harga kopi Karlos ini, konsumen memilih karena rasa yang unik yang dimiliki oleh kopi Karlos.

Berdasarkan cara yang telah dikemukakan oleh Kotler dan Keller tidak semua indikator yang ada di positioning ada terdapat pada kopi Karlos. Sehingga dapat disimpulkan positioning pada kopi Karlos terdapat pada produk kopi Karlos. Karena produk kopi Karlos lebih unggul dibandingkan dengan kopi lainnya. Produk kopi Karlos lebih unggu dibandingkan dengan kopi lainnya karena kopi Karlos memiliki rasa yang unik dari proses pengolahannya sehingga menciptakan rasa yang unik. Rasa yang unik tersebut dipertahankan dengan cara menjaga dan mengawasi 


\section{SWOT}

setiap proses pengolahan kopi Karlos sehingga kopi Karlos bisa lebih unggul dibandingkan dengan kopi lainnya.

a. Strength

Strength atau kekuatan di dalam analisis SWOT merupakan kompetisi khusus yang memberikan keunggulan kompetitif bagi perusahaan di pasar. Berdasarkan penyajian data, strength dari produk kopi Karlos adalah tersedianya berbagai jenis Kopi Karlos berdasarkan pengolahannya, salah satunya yaitu jenis Honey. Kopi Karlos jenis Honey memiliki rasa asam sitrus atau asam buah apel yang berbeda dari kopi jawa pada umumnya, sehingga memiliki nilai pembeda dibandingkan dengan kopi lain. Dari segi harga, Kopi Karlos dijual dengan harga yang terjangkau.

b. Weakness

Kelemahan adalah keterbatasan atau kekurangan dalam sumber daya, keterampilan, dan kapabilitas yang secara efektif menghambat kinerja perusahaan. Kopi Karlos memiliki kelemahan pada segi proses. Kopi Karlos memiliki dua jenis kopi Full Wash dan Semi Wash. Meskipun dibedakan berdasarkan cara pemrosesan atau pengolahan, produk Full wash maupun Semi Wash sama-sama memiliki kadar gula tinggi dan sudah cukup untuk mengeluarkan semua rasa. Konsistensi pengolahan biji kopi pasca panen juga menjadi tantangan bagi produsen Kopi Karlos. Kelebihan atau kekurangan waktu untuk fermentasi dan menggoreng biji kopi Karlos yang memiliki perbedaan ukuran biji kopi juga berdampak pada rasa yang keluar dari kopi tersebut.

c. Opportunity

Peluang adalah situasi penting yang menguntungkan dalam lingkungan perusahan .
Kecendrungan - kecendrungan penting merupakan salah satu sumber peluang, seperti perubahaan teknologi dan meningkatnya hubungan antara perusahaan dengan pembeli atau pemasok merupakan gambaran peluang bagi perusahaan. Peluang yang dimiliki oleh produsen Kopi Karlos adalah meningkatnya jumlah penikmat kopi Karlos tahun ini. Banyaknya penikmat kopi yang mencapai titik jenuh dalam menikmati berbagai macam kopi dan beralih ke kopi lokal akan sangat menguntungkan produsen kopi Karlos dalam memasarkannya, khususnya bagi kalangan mahasiswa. Selain itu, penjualan kopi bubuk juga sedang meningkat di pasaran. Hal tersebut tentu akan menguntungkan produsen Kopi Karlos dalam memperluas target konsumennya berupa roastry ataupun kalangan home brewer.

d. Threat

Ancaman adalah situasi penting yang tidak menguntungan dalam lingkungan perusahaan. Ancaman merupakan pengganggu utama bagi posisi sekarang atau yang diinginkan perusahaan. Kopi Karlos memiliki banyak pesaing dari produsen-produsen kopi lokal sendiri, misalnya produsen kopi dari Pujon, Selekta yang samasama berjenis kopi arabika dan memiliki umur yang sama dengan Kopi Karlos. Dari daerah Karangploso, Malang sendiri juga memiliki pesaing, yaitu produsen Kopi Arjuno.

\section{Simpulan}

Berdasarkan hasil analisis dari peneliti, didapatkan beberapa kesimpulan, yaitu : Segmenting, Segmenting Kopi Karlos terdapat pada masyarakat menengah kebawah. Hal tersebut dikarenakan harga Kopi Karlos yang relatif lebih murah dibandingkan dengan kopi lokal lainnya. Meskipun murah, kualitas Kopi Karlos tidak kalah dengan kopi lokal lainnya. Karena pada dasarnya masyarakat lebih 
menyukai karakter kopi yang sesuai dengan lidah mereka. Segmentasi psikografik Kopi Karlos tidak bisa dibedakan berdasarkan karakteristik sosial, gaya hidup, maupun kepribadian penikmat kopi. Penikmat kopi hanya menikmati jenis kopi yang ingin mereka konsumsi tergantung selera mereka masing-masing. Kecenderungan konsumen kopi untuk mengonsumsi Kopi Karlos hanya dipengaruhi oleh selera konsumen pada saat itu. Targetting, Target dari Kopi Karlos yakni mahasiswa dan berjenis laki-laki. Kopi Karlos memiliki banyak penikmat dari tahun ke tahun. Hal ini didasari adanya titik jenuh para penikmat kopi dalam mencoba berbagai jenis kopi dan beralih ke kopi lokal. Jumlah penikmat Kopi Karlos tahun ini semakin meningkat. Hal tersebut karena penikmat kopi lokal yang semakin meningkat. Positioning, Kopi Karlos memposisikan produknya dengan cita rasa kopi yang asam di akhir. Cita rasa ini menentukan posisi penting Kopi Karlos di pasar karena menjadi pembeda dibandingkan kopi lokal lain. Perbedaan waktu penjemuran, fermentasi, dan penggorengan yang berbeda dari semestinya akan berpengaruh pada rasa yang keluar dari kopi tersebut. SWOT, Kekuatan dari Kopi Karlos adalah tersedianya berbagai jenis Kopi Karlos berdasarkan pengolahannya, salah satunya yaitu jenis Honey. Kopi Karlos jenis Honey memiliki rasa asam sitrus atau asam buah apel yang berbeda dari kopi jawa pada umumnya, sehingga memiliki nilai pembeda dibandingkan dengan kopi lain. Kelemahan pada konsistensi pengolahan biji kopi pasca panen juga menjadi tantangan bagi produsen Kopi Karlos. Kelebihan atau kekurangan waktu untuk fermentasi dan menggoreng biji kopi Karlos yang memiliki perbedaan ukuran biji kopi juga berdampak pada rasa yang keluar dari kopi tersebut. Peluang yang dimiliki oleh produsen Kopi Karlos adalah meningkatnya jumlah penikmat kopi kopi lokal dan kopi Karlos termasuk mengalami peningkatan yang cukup tinggi karena harganya yang murah. Ancaman kopi Karlos adalah munculnya banyak pesaing dari produsen-produsen kopi lokal. Produsen Kopi lokal tersebut antara lain adalah kopi arjuno dan kopi pujon, yang keduanya sama sama berjenis kopi arabika dan berasal dari daerah malang.

\section{Saran}

Akademis, untuk penelitian lebih lanjut mengenai strategi pemasaran Kopi Karlos sebagai upaya meningkatkan Kopi Karlos sebagai produk lokal unggulan daerah. Praktis, diperlukan pelatihan sumber daya manusia yang memadai dalamkonsistensi pengelolaan kopi lokal pasca panen. Perlunya alat yang lebih modern dalam membantu proses pengolahan kopi.

\section{Daftar Pustaka}

Ade, M Supriyatna SP,dkk.2014.Statistik Lahan Pertanian Tahun 2009 - 2013.Jakarta: Pusat Data dan Sistem Informasi Pertanian Sekretariat Jenderal - Kementerian Pertanian 2014.

Afianda, M Putra. 2015. Strategi Pemasaran Dalam Meningkatkan Volume Penjualan pada CV Waty Grafika Medan. Jurnal Ilmiah Integritas. Vol.1, No.3.

Alyandra,Fikri.2014.Berapa Sebenarnya Luas Lahan Pertanian di Indonesia. http://www.kompasiana.com/fikri alyandra/ berapa-sebenarnya-luas-lahan-pertanian-diindonesia 54f9548ba3331176178b4bbd (online), Diakses 25 Mei 2017.

Dimas, dkk. 2015. Analisis Strategi Pemasaran untuk Meningkatkan Daya Saing UMKM (Studi pada Batik Diajeng Solo).Universitas Brawijaya.Jurnal Administrasi Bisnis (JAB). Vol. 29, No. 1

Fandi AhmadMunadi. 2015. Analisis Strategi Pemasaran untuk Meningkatkan Penjualan Kendaraan Motor pada CV Turangga Mas Motor. Fakultas Ekonomi Universitas Gunadarma.

Fauziah, F. 2016. Pengaruh strategi pemasaran dan kualitas prduk terhadap keputusan pembelian di CV. Monita Food. Bandung:Universitas Widyatama

H,Tunjung.2014. Analisis efisiensi pengelolaan persedian bahan baku kedelai pada perusahaan kecap PT Lombok Gandaria Food Industry Palur Karanganyar.Universitas Sebelas Maret. 
Istiatin dan Sudarwati. 2015. Analisis Strategi Pemasaran Bisnis Retail di Lottemart Surakarta.Jurnal Paradigma. Vol.12,No.02.

Karang Ploso,Donorawih.Profil Desa Donorawih Kecamatan Karangploso. http://donowarihkarangploso.blogspot.co.id/ $2010 / 12 /$ profil-desa-donowarihkecamatan.html (online),Diakses $25 \mathrm{Mei}$ 2017.

Kasali, Rhenald.2001. Membidik Pasar $\begin{array}{llllllllllllll} & n & t & e & r & n & a & t & i & o & n & a & l\end{array}$ : Segmentasi,Targetting,Positioning. PT. Gramedia Pustaka Utama:Jakarta

Kasali, Rhenald. 2003. Marketing Public Relations. PT Temprint:Jakarta.

Keegan dan Green. 2008.Global Marketing. Edisi 5. London Pearson Education:Jakarta

Kismono, Gugup. 2011. Bisnis PengantarEdisi Dua. BPFE UGM:Yogyakarta

Kotler, Amstrong. 2001. Prinsip-prinsip pemasaran, Edisi keduabelas, Jilid 1.Erlangga:Jakarta

Kotler, Philip dan Kevin Lane Keller. 2008. Manajemen Pemasaran, Jilid 1. Erlangga.:Jakarta

Lestari, Rini Eka. 2015. IMPLEMENTASI KEBIJAKAN OTONOMI DESA DI DESA P I L A N J A U K C A M A T A N SAMBALIUNG KABUPATEN BERAU. Universitas Mulawarman.
Lihawa,Il.2014.Pengertian Pertanian dan Usaha Tani. http://eprints.ung.ac.id/2271/6/2012-2$54201-614408031-\mathrm{b}$ a b 2 25012013033416.pdf (online), Diakses 25 Mei 2017.

Lubis, Arlina Nurbaity. 2004. Strategi Pemasaran Dalam Persaingan Bisnis. Universitas Sumatera Utara

Moleong, Lexy J. 2008. Metodologi Penelitian Kualitatif. Remaja Rosdakarya:Bandung

Pemerintah Kabupaten Malang.2017.Selayan Padang (online), diakses 25 Mei 2017.

Septiropa, Zamzami. 2010. DESAIN SANITARY LANDFILL PADA TOPOGRAFI EXTREM DI DESA DONOWARIH KECAMATAN KARANGPLOSO KABUPATEN MALANG. Universitas Muhammadiyah Malang

Silalahi, Ulber. 2009. Metode Penelitian Sosial. Refika Editama: Bandung

Swasta, Basu.2004. Manajemen Pemasaran Modern.Liberty:Yogyakarta.

Sugiyono. 2016. Metode Penelitian Kuantitatif, Kualitatif, dan RED. Bandung: Alfabeta

Sugiyono. 2012. Metode Penelitian. Bandung: Alfabeta

Tjiptono, Fandy.2002. Strategi Pemasaran Edisi 2.Andi,:Yogyakarta 